\title{
Perancangan Buku Visual Eksplorasi Motif Batik Ponorogoan sebagai Upaya Pelestarian Warisan Budaya Daerah
}

\author{
Dhamar Mawardhi dan Senja Aprela Agustin \\ Departemen Desain Produk, Fakultas Arsitektur, Desain dan Perencanaan, \\ Institut Teknologi Sepuluh Nopember (ITS) \\ e-mail: senja@prodes.its.ac.id
}

\begin{abstract}
Abstrak-Perkembangan batik printing membuat batik Ponorogo pada awal abad ke-20 kalah bersaing di pasaran sehingga saat ini hanya terdapat dua ornamen utama dalam batik Ponorogo, yaitu merak dan reyog. Hal ini disebabkan oleh kurangnya kreatifitas pengrajin untuk mengembangkan motif batik Ponorogo. Sehingga dibutuhkanlah sebuah media yang bisa memberikan informasi bagi pengrajin batik Ponorogo dan generasi penerusnya untuk mengembangkan motif batik Ponorogo. Perancangan buku visual ini menggunakan beberapa metode penelitian diantaranya observasi langsung, kuisioner, wawancara mendalam, visual exploration, expert review, studi eksisting dan literatur. Data yang didapat kemudian diformulasikan untuk mendapatkan sebuah konsep desain dan konten buku yang sesuai. Konsep perancangan ini adalah "Heritage Rough Forms" yang dapat bermakna pencarian motif baru yang diambil dari potensi heritage Ponorogo yang dikombinasikan dengan komponen dari motif batik klasik Ponorogo. Hasil luaran dari penelitian ini adalah sebuah buku visual yang berisi informasi sekilas tentang batik pada umumnya, batik Ponorogo pada khususnya dan hasil eksplorasi motif baru batik Ponorogo yang telah dibuat. Penggunaan batik klasik Ponorogo bertujuan untuk memperkuat identitas motif khas batik Ponorogo. Buku visual ini dilengkapi dengan hasil fotografi dan proses desain eksplorasi motif batik Ponorogo yang telah dibuat sehingga dapat memberikan informasi sebagai sarana referensi tentang batik Ponorogo sebagai upaya melestarikan warisan budaya daerah.
\end{abstract}

Kata Kunci-Eksplorasi Motif, Batik Ponorogo, Buku Visual.

\section{PENDAHULUAN}

$\mathrm{K}$ EBUDAYAAN merupakan keseluruhan yang kompleks, yang di dalamnya terkandung pengetahuan, kepercayaan, kesenian, moral, hukum, adat istiadat, dan kemampuankemampuan lain yang didapat seseorang sebagai anggota masyarakat [1]. Sehingga suatu budaya harus dirawat dan dilestarikan untuk menjadi pengetahuan untuk generasi penerus. Indonesia memiliki beragam potensi budaya yang cukup besar untuk terus dilestarikan sesuai dengan kemajuan zaman. Batik merupakan kebudayaan asli Indonesia yang makna dan fungsinya tidak dapat dipisahkan dengan kehidupan sehari-hari masyarakat, khususnya di masyarakat Jawa karena sudah digunakan sejak masa kerajaan. Secara etimologi, batik berasal dari bahasa Jawa "tik" yang memiliki arti titik/matik, yaitu kata kerja membuat titik, yang kemudian berkembang menjadi kata batik [2]. Kata batik atau hambatik (membatik) sendiri menurut sejarah baru dipakai dalam Babad Sengkala yang ditulis pada tahun 1633 dan juga dalam Panji Jaya Lengkara yang ditulis pada tahun 1770 .
Berbagai daerah di Jawa dan tidak terkecuali Jawa Timur mulai melestarikan dan mengembangkan batik tradisional masing-masing daerah sehingga mampu bersaing di level Nasional. Salah satunya adalah kabupaten Ponorogo yang kini masih dalam tahap menggali lagi potensi batiknya yang telah lama tenggelam karena perkembangan industri batik printing pada awal abad ke-20. Industri batik di Ponorogo ada sejak tahun 1921 dengan jenis motif yang terinspirasi dari kesenian reyog Ponorogo dan meraknya dengan teknik tulis. Batik Ponorogo pernah berjaya pada tahun 1960 hingga 1980 karena terkenal dengan batiknya yang tidak luntur karena menggunakan pewarna nila [3].

Motif batik Ponorogo dari dahulu hingga sekarang terkesan tidak mengalami perkembangan karena seni dan keterampilan membatik memang bersifat turun-temurun sehingga hal ini menjadi salah satu masalah perkembangan batik di Indonesia [4]. Kebanyakan pengrajin batik memiliki kemampuan yang terbatas untuk mengembangkan motif batik karena masih terbelenggu dengan motif batik yang sudah ada dan menjadi pakem sejak dahulu. Padahal Kabupaten Ponorogo memiliki potensi daerah yang bisa diangkat ke dalam bentuk motif batik, mulai dari peninggalan budaya, wisata hingga hasil alamnya.

Sebagai upaya untuk mengembalikan kejayaan batik Ponorogo dibutuhkan sebuah upaya untuk mengembangkan industri batik di Kabupaten Ponorogo. Salah satu upaya yang dapat dilakukan adalah dengan melakukan pengembangan motif batik Ponorogo. Eksplorasi motif batik Ponorogo yang diambil dari potensi daerah Ponorogo, yang menjadi ciri khas motif batik pedalaman, merupakan salah satu upaya pelestarian batik khas Ponorogo. Hasil eksplorasi motif batik Ponorogo kemudian dikemas dalam sebuah media buku visual sebagai media referensi dan informasi tentang batik Ponorogo sebagai upaya pelestarian batik motif Ponorogoan.

\section{A. Identifikasi Masalah}


1) Motif batik Ponorogo sudah ada sejak tahun 1921, namun hingga kini hanya terdapat dua buah komponen utama yang dominan dalam produk batik Ponorogo yaitu merak dan reyog sehingga belum ada pengembangan motif baru yang sesuai dengan kebutuhan dan perkembangan pasar.

2) Kabupaten Ponorogo memiliki potensi daerah yang dapat dijadikan motif batik, namun pengrajin batik memiliki kemampuan yang terbatas untuk mengembangkan motif batik.

3) Semakin berkembangnya industri batik daerah lain dapat membuat batik Ponorogo akan hilang di pasaran karena kurangnya usaha untuk mengembangkan batik Ponorogo yang sudah terkesan monoton.

4) Batik Ponorogo layak untuk terus dilestarikan karena merupakan warisan budaya daerah dengan sebuah media informasi dan referensi bagi generasi penerus dan pengrajin batik khas Ponorogo.

\section{B. Rumusan Masalah}

Bagaimana merancang sebuah buku visual eksplorasi motif batik Ponorogo yang diangkat dari potensi daerah Ponorogo sebagai upaya pelestarian warisan budaya daerah?

\section{Batasan Masalah}

1) Permasalahan yang akan diselesaikan dalam perancangan ini berkaitan dengan penciptaan dan eksplorasi desain motif batik Ponorogo.

2) Konten yang terdapat dalam buku visual ini meliputi pengenalan daerah Ponorogo dan hasil eksplorasi motif batik Ponorogoan beserta proses penciptaannya.

3) Fokus media yang digunakan berupa buku visual dalam bentuk cetak.

\section{Tujuan}

1) Memperkaya motif batik Ponorogo sehingga mampu bersaing dengan ragam hias batik lain di pasaran.

2) Memperkuat ragam hias batik Ponorogo dengan mengangkat potensi daerah Kabupaten Ponorogo dalam media batik.

3) Memberikan stimulus kepada pengrajin batik untuk melestarikan warisan budaya daerah sehingga batik Ponorogo bisa tetap bertahan di tengah industri batik daerah yang terus berkembang.

Membuat sebuah media sebagai sarana informasi dan referensi tentang batik Ponorogo.

\section{STUDI PUSTAKA}

\section{A. Landasan Teori}

1) Tinjauan tentang Batik

Batik merupakan salah satu warisan budaya yang secara turun temurun diwariskan oleh nenek moyang Bangsa Indonesia. Istilah batik diperkirakan berasal dari bahasa Jawa amba (menulis) dan titik [5].

2) Tinjauan tentang Batik Ponorogoan

Motif batik Ponorogoan memiliki ciri khas visual yang diambil dari kehidupan sehari-hari masyarakat Ponorogo dikarenakan batik Ponorogo merupakan salah satu batik pedalaman. Hal ini membuat motif batik Ponorogo memiliki filosofi tentang makna kehidupan masayarakat Ponorogo [6].

3) Tinjauan tentang Buku Visual

Buku visual merupakan sebuah media yang terbentuk dari lembaran kertas berjilid yang didalamnya terdapat elemen-elemen visual seperti, gambar, fotografi, bagan lebih mendominasi daripada elemen tulisan.

\section{B. Studi Eksisting}

1) Batik Solo merupakan jenis batik yang memiliki nilai sejarah yang tinggi sehingga mampu menarik perhatian pasar.

2) Batik Tulungagung dan Solo memiliki detail latar belakang yang baik sehingga memiliki kesan bernilai jual lebih tinggi.

3) Batik Mataraman biasanya memiliki filosofi yang tinggi dengan motif batik yang diambil dari kegiatan yang dilakukan maupun hal-hal yang dilihat pembatik setiap harinya.

4) Pembahasan tentang batik Ponorogo dalam buku Keeksotisan Batik Jawa Timur, Memahami Motif dan Keunikannya oleh Mohamad Yusak Anshori cukup ringkas dan hanya mendokumentasikan sejarah singkat serta beberapa motif saja tanpa mengeksplorasi secara lengkap motif batik Ponorogo.

\section{METODE PENELITIAN}

\section{A. Metode Pengumpulan Data}

Tahap pengumpulan data untuk mengumpulkan berbagai data yang diperlukan dalam perancangan ini dibagi dua aspek fokus penelitian, yaitu fokus penelitian untuk perancangan motif batik Ponorogo dan fokus penelitian untuk perancangan buku visual. Metode penelitian yang digunakan pada proses perancangan ini adalah metode kualitatif dan kuantitatif, hal ini dilakukan karena membutuhkan penelitian yang komprehensif untuk mendapatkan data yang lengkap dan akuran sehingga mampu menghasilkan konten yang baik bagi target audiens dengan melakukan metode observasi, depth interview, kuisioner, studi literatur dan eksisting, visual exploration dan expert review.

\section{B. Data Primer}

1) Observasi

Observasi dilakukan di pengrajin batik khas Ponorogo yang masih ada dan Dinas Perdagangan Koperasi dan Usaha Mikro Kabupaten Ponorogo yang memiliki data terkait batik Ponorogo yang lengkap.

2) Kuisioner

Penyebaran kuisioner ini dilakukan untuk mengetahui jumlah kepemilikan produk batik Ponorogo di masyarakat, khususnya masyarakat Ponorogo. Kuisioner ini mayoritas disebarkan melalui online dengan target masyarakat Ponorogo. Minimal jumlah responden dari kuisioner ini berjumlah minimal 100 dengan kriteria untuk mencari permasalahan terhadap batik Ponorogo.

3) Depth Interview

Depth Interview dilakukan kepada beberapa orang yang memiliki peranan penting dalam penelitian ini, seperti kepala Dinas Perdagangan Koperasi dan Usaha Mikro 
Kabupaten Ponorogo dan pengrajin batik Ponorogo. Selain itu, hasil dari depth interview juga dilakukan kepada dinas budaya dan pariwisata kabupaten Ponorogo untuk mengetahui potensi kabupaten Ponorogo untuk diangkat ke dalam motif batik.

4) Visual Eksploration

Proses penelitian visual eksploration ini digunakan untuk mengeksplorasi konsep, bentuk hingga usability sebuah desain. Proses ini digunakan untuk menyampaikan ide dan menyamakan pemahaman tentang desain yang akan dibuat kepada stakeholder yang terkait dengan proses perancangan eksplorasi motif batik Ponorogoan ini

5) Expert Review

Proses penelitian ini akan memberikan masukan terhadap eksplorasi motif batik Ponorogo yang telah dibuat.

\section{Data Sekunder}

\section{1) Studi Literatur dan Eksisting}

Studi ini merupakan suatu proses metode kualitatif yang dilakukan dengan cara menganalisa batik Ponorogo dan buku visual tentang batik Ponorogo yang sudah ada sebelumnya dari berbagai sumber.

\section{HASIL DAN PEMBAHASAN}

\section{A. Observasi}

1) Batik Ponorogo termasuk dalam kategori batik pedalaman sehingga memiliki motif yang terinspirasi dari kehidupan sehari-hari masyarakatnya.

2) Motif batik Ponorogo sangat terpengaruh oleh peninggalan leluhur seperti kesenian Reyog Ponorogo, Merak, dan lain sebagainya.

3) Pembuatan layout batik dengan menggunakan perkiraan implementasi akan memudahkan dalam proses tata letak ornamen utama, ornamen pengisi dan isen-isen dalam selembar kain batik.

4) Adanya motif batik klasik bentuk kasar Ponorogoan yang kini sulit ditemui di pasaran karena dianggap terlalu kuno namun memiliki makna dalam motif-motifnya.

\section{B. Depth Interview}

1) Hingga tahun 2017, motif batik Ponorogoan masih terbatas di motif dengan komponen utama reyog dan merak.

2) Pengrajin batik di Ponorogo belum memiliki kemampuan yang cukup untuk mengembangkan motif batik Ponorogoan.

3) Sebagian besar produk batik Ponorogo masih merupakan pesanan untuk seragam Pegawai Negeri Sipil dan siswa sekolah di lingkup Pemerintah Kabupaten Ponorogo.

4) Adanya motif batik klasik bentuk kasar Ponorogoan yang kini sulit ditemui di pasaran karena dianggap terlalu kuno namun memiliki makna dalam motif-motifnya.

\section{Kuisioner}

1) Mayoritas masyarakat Ponorogo yang memiliki produk batik tidak memiliki produk batik dengan motif khas Ponorogo.
2) Adanya motif batik klasik bentuk kasar Ponorogoan yang kini sulit ditemui di pasaran karena dianggap terlalu kuno namun memiliki makna dalam motif-motifnya.

3) $54,6 \%$ responden tidak mengetahui tentang batik Ponorogo.

4) Mayoritas responden menganggap tidak ada upaya untuk mengembangkan batik Ponorogo sehingga motifnya terbatas dan terkesan monoton.

5) $98,1 \%$ responden mengakui diperlukannya usaha untuk mengembangkan motif batik Ponorogo sehingga bisa mengangkat kembali kejayaan industri batik Ponorogo. 


\section{Studi Literatur}

1) Elliott, Inger McCabe. 2004. Batik Fabled Cloth of Java. Jakarta. Java Books Indonesia

2) Kusrianto, Adi dan Yusak Anshori. 2011. Keeksotisan Batik Jawa Timur. Jakarta. Elex Media Komputindo

3) Sumarsono, Hartono dkk. 2013. Benang Raja: Menyimpul Keelokan Batik Pesisir. Jakarta: Kepustakaan Populer Gramedia

4) Krevitsky, Nik. 1964. Batik Art and Craft. New York: Reinhold Publishing Corporation

5) Kusrianto, Adi. 2013. Batik Filosofi, Motif dan Kegunaan. Yogyakarta: Penerbit ANDI

6) Supriono, Primus. 2016. The Heritage of Batik: Identitas Pemersatu Kebanggaan Bangsa. Yogyakarta: Penerbit ANDI

\section{E. Studi Eksisting}

1) Batik Mataraman

2) Batik Tulungagung

3) Batik Solo

4) Buku Keeksotisan Batik Jawa Timur, Memahami Motif dan Keunikannya oleh Mohamad Yusak Anshori.

\section{F. Visual Eksploration}

1) Ornamen utama dalam motif batik memiliki porsi yang lebih besar dalam sebuah layout motif batik sehingga mampu memberikan identitas mudah yang mudah dipahami.

2) Bentuk motif sate Ponorogo belum bisa memiliki identitas yang kuat sebagai motif batik Ponorogoan karena kuliner jenis sate banyak ditemui di banyak tempat lain, khususnya di pulau Madura. Hal ini juga berlaku untuk motif batik dengan ornamen Kampung Durian, Ponorogo yang dikarenakan durian merupakan buah yang sudah umum ditemukan di berbagai daerah

3) Motif batik dengan ornamen utama Warok dan Klono Sewandana lebih diutamakan karena merupakan bagian asli dari Ponorogo yang telah menjadi bagian pedoman hidup dari masyarakat Ponorogo. Di sisi lain, reyog Ponorogo merupakan sebuah kesenian yang diciptakan oleh Ki Ageng Kutu untuk menyindir Raja Majapahit karena terlalu patuh terhadap kehendak sang permaisurinya.

4) Setiap motif batik sebaiknya mempunyai latar belakang yang kuat sehingga mampu dipahami dengan baik dan memiliki identitas serta nilai yang tinggi jika sudah menjadi produk kain batik nantinya.

\section{G. Expert Review}

1) Di dalam penyusunan ornamen-ornamen batik ke dalam sebuah layout motif batik harus menyatu di kedua ujungnya.

2) Proses pewarnaan dalam batik klasik minimal tiga kali untuk mendapatkan kesan batik klasik.

3) Warna batik klasik Ponorogoan adalah biru gelap yang bisa didapatkan dengan melakukan proses lasem yang merupakan proses terakhir pada pewarnaan kain batik.

4) Susunan pewarnaan motif batik harus diperhatikan untuk mengefisiensi proses membatik.
5) Peletakan unsur merak pada motif reyog sebaiknya tidak diletakkan di atas kepala barong, namun diletakkan di bagian sisi samping kepala barong.

6) Motif warok sebaiknya menggunakan visualisasi kolor dan celana kain hitamnya karena bentuk visualisasi wajah warok terlalu maskulin untuk dijadikan motif batik.

7) Pewarnaan batik menjadi salah satu unsur terpenting dalam membuat batik karena warna bisa menjadi sebuah identitas tersendiri untuk sebuah produk batik.

\section{KONSEP DESAIN}

\section{A. Konsep Desain}

Konsep desain dari perancangan motif batik Ponorogo ini adalah "Heritage Rough Forms" yang dapat bermakna sebagai eksplorasi motif baru batik Ponorogo yang merupakan kombinasi antara potensi heritage daerah Ponorogo dengan bentuk batik klasik kasar Ponorogoan. Hasil dari perancangan ini menampilkan informasi tentang batik Ponorogo dan hasil eksplorasi motif batik Ponorogo yang telah dibuat ke dalam sebuah buku visual.

\section{B. Kriteria Desain Eksplorasi Motif Batik Ponorogoan}

\section{1) Eksplorasi Motif Batik Ponorogoan}

Motif batik Ponorogo yang dibuat merupakan hasil eksplorasi dari potensi heritage Kabupaten Ponorogo. Selanjutnya dari potensi-potensi heritage daerah Ponorogo yang ada kemudian dipilih beberapa potensi yang paling sesuai dengan karakteristik Ponorogo sehingga bisa mewakili ciri khas Ponorogo dalam motif batik. Potensi daerah yang telah terpilih dikelompokkan ke dalam 3 kategori yaitu bentuk besar yang kemudian disebut Hyang Mandhap Partala, harmonis yang kemudian disebut Ajeging Werna Windraya dan geometris yang kemudian disebut Kawarna Gendhaga Kubuk. Di dalam setiap motif yang dibuat nantinya akan menyertakan komponen dari motif batik sekar jagad Ponorogo yang berupa batik kasar.

2) Buku Visual

Struktur buku kaya rupa eksplorasi batik Ponorogo ini akan dibagi menjadi tiga bagian. Bagian satu berisi tentang pengenalan Kabupaten Ponorogo dan batik secara ringkas. Bagian dua berisi hasil eksplorasi motif batik Ponorogo yang baru. Sedangkan bagian tiga berisi eksplorasi warna batik, tantangan batik Ponorogoan, kepustakaan dan index buku visual.

\section{Proses Desain}

\section{1) Eksplorasi Motif Batik Ponorogoan}

Terdapat tiga layout pola batik utama yang digunakan dalam menyusun eksplorasi motif batik Ponorogoan ini, yaitu pola motif bentuk besar, pola dinamis dan pola geometris. Di samping itu juga terdapat pola kontemporer yang diadaptasi dari pola batik pesisir dan juga pola batik bebas dengan pola layout motif tidak terikat makna di setiap ornamen utamanya yang terinspirasi dari pola batik pesisir. 


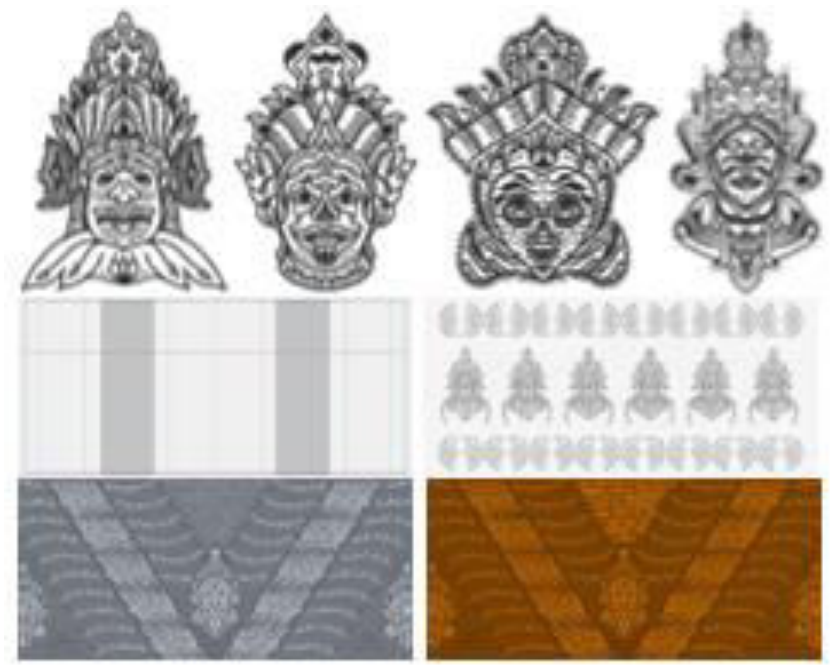

Gambar 1. Proses eksplorasi motif batik Ponorogoan.

\section{2) Buku Visual}

Sistem layout buku yang digunakan dalam perancangan buku visual ini terbagi menjadi dua buah grid yaitu column grid dan modular grid. Penggunaan dua sistem grid ini akan memudahkan dalam penyusunan konten pada setiap halaman buku visual sehingga pembaca memiliki ruang untuk memahami setiap konten verbal dan visual dengan lebih baik.
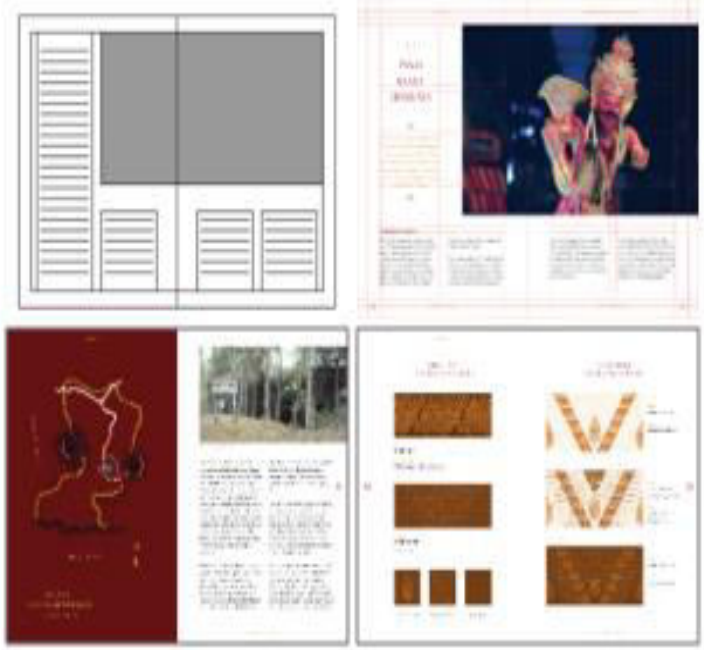

Gambar 2. Proses desain buku visual.

\section{IMPLEMENTASI DESAIN}

\section{A. Eksplorasi Motif Batik Ponorogoan}

1) Hyang Mandhap Pertala

Hasil eksplorasi motif batik Ponorogoan yang pertama adalah kelompok motif dengan pola dengan ornamen utamanya berukuran besar. Kelompok dengan pola ini kemudian disebut dengan Hyang Mandhap Pertala.
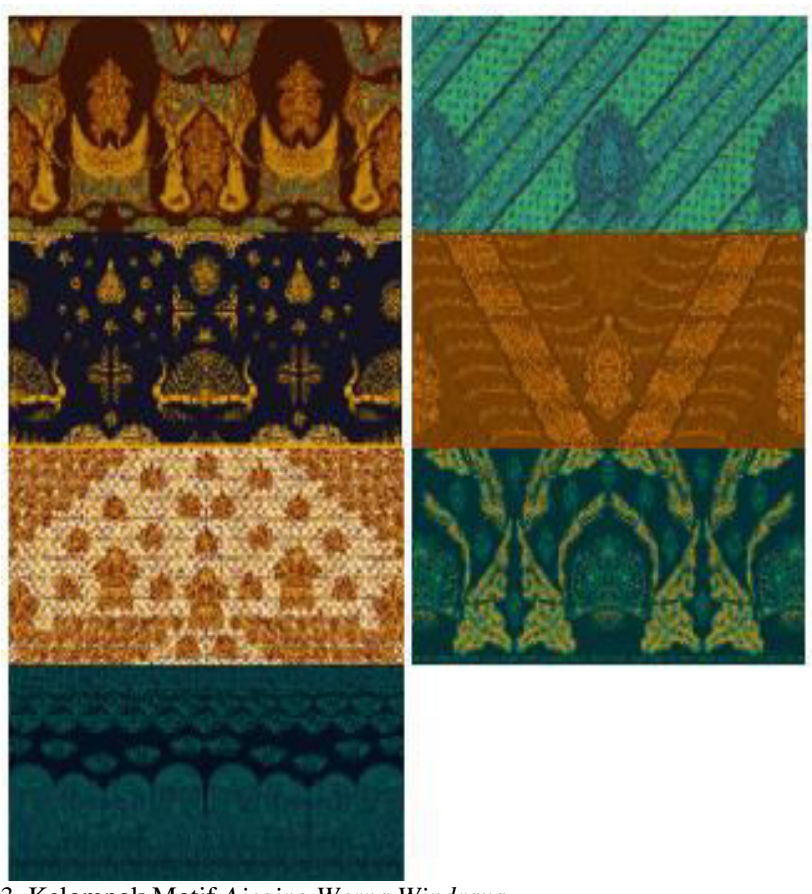

Gambar 3. Kelompok Motif Ajeging Werna Windraya.

2) Ajeging Werna Windraya

Kelompoka eksplorasi motif yang kedua adalah Ajeging Werna Windraya. Kelompok eksplorasi motif ini berpola harmonis, yaitu persebaran ornamen utama dan komponen lainnya yang diatur merata pada sebuah kain batik.
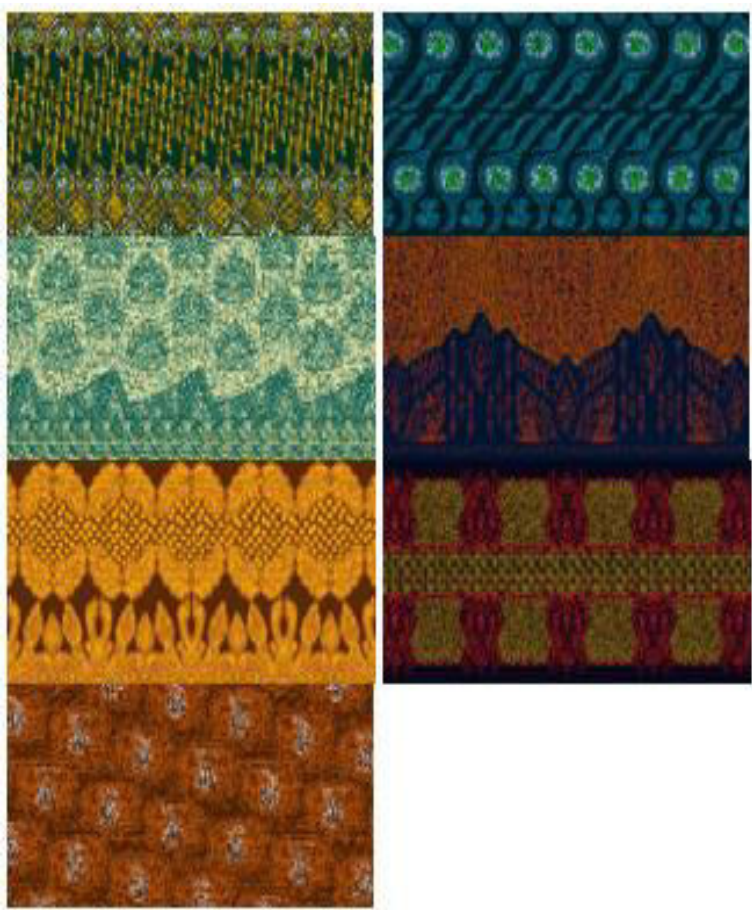

Gambar 4. Kelompok Motif Ajeging Werna Windraya.

3) Kawarna Gendhaga Kubuk

Pola hasil ekplorasi motif batik yang ketiga adalah Kawarna Gendhaga Kubuk. Di dalam kelompok ini 
terdapat kumpulan eksplorasi motif batik dengan pola geometris.

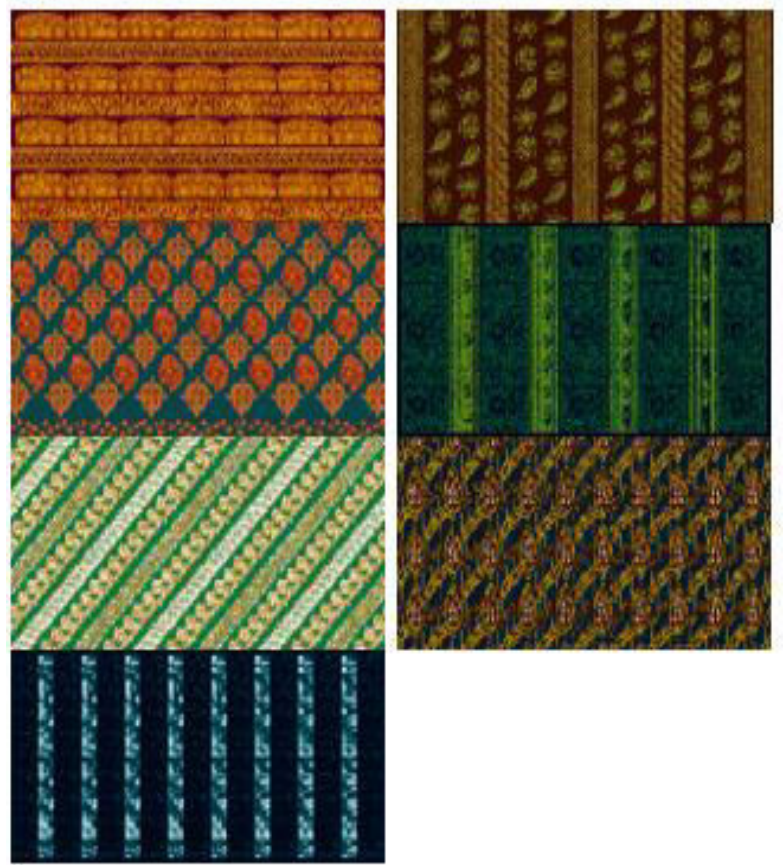

Gambar 5. Kelompok Motif Kawarna Gendhaga Kubuk.

4) Motif Kontemporer

Ornamen utama motif batik di dalam kelompok motif kontemporer ini diambil dari sesuatu yang sedang populer di Kabupaten Ponorogo saat ini. Di samping itu, proses pewarnaan dari motif ini menggunakan warna yang lebih cerah dan terdapat inspirasi dari pola motif batik pesisiran.

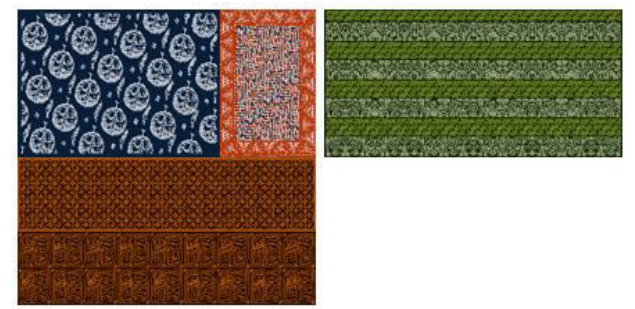

Gambar 6. Kelompok Motif Kontemporer.

5) Motif Sekunder

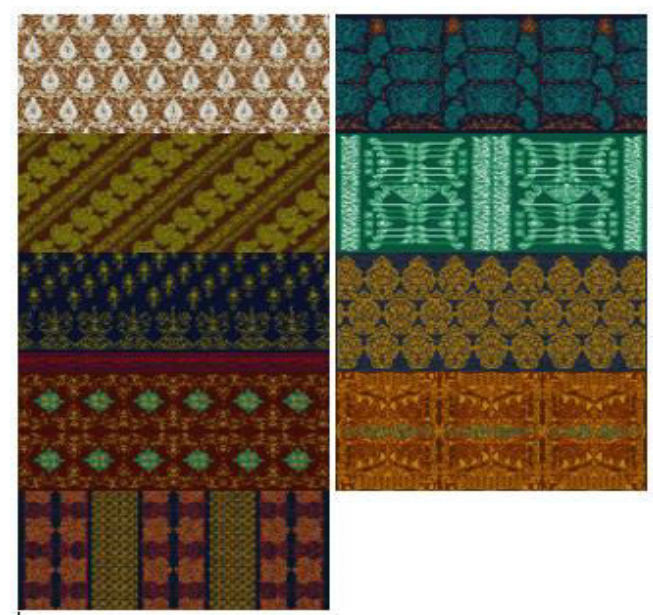

Gambar 7. Kelompok Motif Sekunder.
Kelompok motif sekunder adalah hasil eksplorasi motif batik Ponorogoan yang merupakan kombinasi dari motif batik klasik Ponorogoan dengan ornamen utama yang merupakan heritage daerah Ponorogo. Namun, di dalam proses kombinasi kelompok motif ini tidak memperhatikan makna batik sehingga hasil eksplorasi motif batik dalam kelompok ini tidak memiliki makna baru yang terbentuk dalam setiap motifnya,

\section{B. Buku Visual Eksplorasi Motif Ponorogoan}

Implementasi desain utama dalam perancangan ini adalah sebuah buku visual kumpulan eksplorasi motif Ponorogoan yang telah dibuat. Buku visual ini memiliki 3 buah bagian utama. Bagian pertama terbagi menjadi dua bab, yaitu pengenalan tentang Kabupaten Ponorogo dan batik Ponorogoan. Bagian kedua berisi tentang hasil eksplorasi motif batik Ponorogoan yang terbagi menjadi tiga bab, yaitu pola Hyang Mandhap Pertala, Ajeging Werna Windraya dan Kawarna Gendhaga Kubuk. Sedangkan bagian terakhir terbagi menjadi dua bab yang berisi tentang eksplorasi motif batik dan tantangan batik Ponorogoan kedepannya.

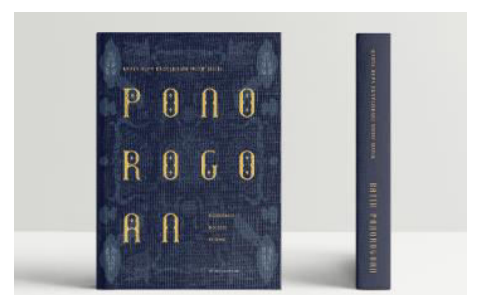

Gambar 8. Tampilan Buku Visual Eksplorasi Motif Batik Ponorogoan.
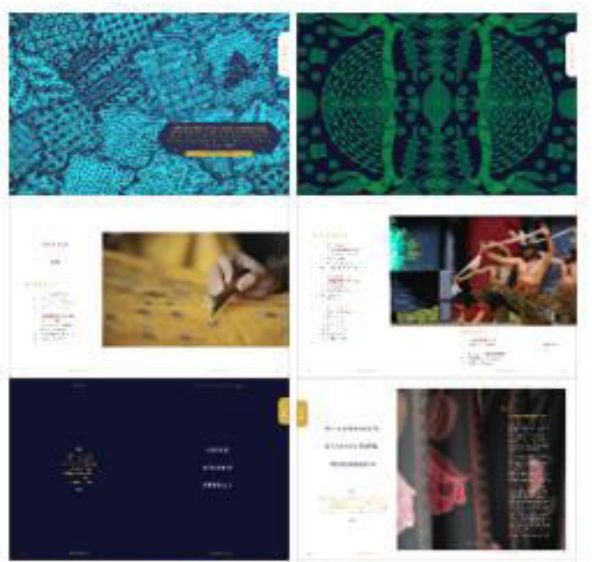

F=
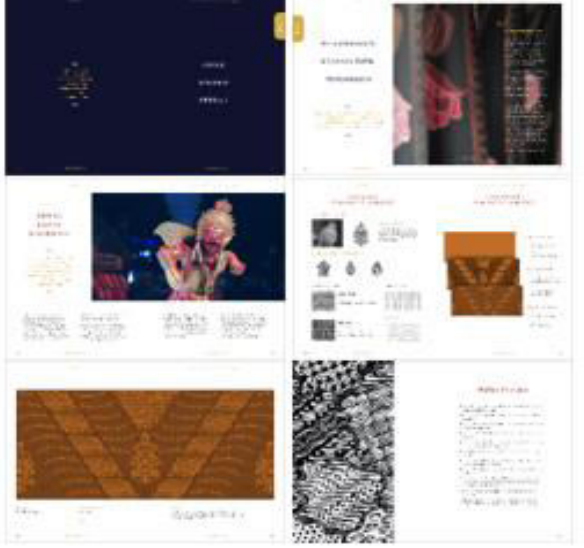

Gambar 9. Layout Buku Visual.

Buku visual eksplorasi motif batik Ponorogoan ini memiliki ukuran 18,5 × 26 centimeter dengan tebal buku 2 centimeter. 
Jumlah halaman dalam buku visual ini adalah xi +185 halaman. Halaman buku menggunakan kertas Lessebo yang tergolong jenis kertas book paper. Sedangkan pada bagian cover buku menggunakan jilid hard cover dengan finishing doff.

Tipografi kata "Batik Ponorogoan" menggunakan huruf custom yang dibuat dengan menyesuaikan dengan konsep Heritage Rough Forms pada desain final yang dihasilkan. Sedangkan di atas judul utama, terdapat sub judul yang bertuliskan "Karya Rupa Eksplorasi Motif Batik" dengan jenis huruf Unique. Kemudian di bawah judul utama terdapat konsep eksplorasi motif batik Ponorogoan ini yaitu "Heritage Rough Forms" yang dieksekusi dengan jenis huruf Merriweather.

Pada perancangan buku visual eksplorasi motif batik Ponorogoan ini terdapat sepuluh bagian layout buku. Bagianbagian layout buku itu meliputi front matter, daftar isi, pembatas bagian, pembuka bab, bab 1, bab 2, bab 3-5, bab 6, bab 7 dan end matter. Masing-masing bagian layout buku memiliki identitas dan konten yang berbeda.

Elemen visual dalam perancangan buku visual eksplorasi motif batik Ponorogoan ini meliputi judul buku, kickers, judul bab, deck, body text, quotes dan caption. Setiap elemen visual memiliki fungsinya masing-masing sebagai pendukung visualisasi final desain yang dihasilkan.

\section{KESIMPULAN}

Hasil eksplorasi desain motif batik Ponorogo yang telah dibuat kemudian dikemas dalam sebuah buku visual yang juga berisi tentang informasi tentang pewarnaan batik yang merupakan salah satu proses paling vital dalam membatik. Di dalam buku visual yang telah disusun terdapat hasil eksplorasi motif batik sebanyak 21 motif utama, 3 motif dengan ornamen kontemporer dan 9 motif sekunder batik Ponorogo yang baru diharapkan mampu menstimulus para pengrajin pemula maupun pengrajin batik Ponorogo yang sudah ada untuk terus mengembangkan dan melestarikan motif batik Ponorogo. Pada perancangan selanjutnya dapat ditambahkan konten informasi tentang batik secara umum yang mampu memberikan gambaran tentang perbandingan komponen jenis-jenis pola batik. Hal ini bertujuan untuk mempermudah pembaca dalam membedakan ciri khas batik Ponorogo dengan batik daerah lainnya.

\section{DAFTAR PUSTAKA}

[1] E. B. Taylor, Primitive Culture. United Kingdom: Cambridge University Press, 2012.

[2] B. Anas, Indonesia Indah "Batik" Buku ke-8. Jakarta: Yayasan Harapan Kita, 1997.

[3] Y. Anshori and A. Kusrianto, Keeksotisan Batik Jawa Timur. Jakarta: PT. Elex Media Komputindo, 2011.

[4] Y. P. Supriono, Ensiklopedia The Heritage Of Batik, Identitas Pemersatu Kebanggaan Bangsa. Yogyakarta: Penerbit Andi, 2016.

[5] Ministry of Trade, Indonesian Batik: A Cultural Beauty. Trade Research \& Development Agency, 2008.

[6] A. Kusrianto, Batik-Filosofi, Motif, dan Kegunaan. Yogjakarta: Penerbit Andi, 2013. 